\title{
Antenatal dexamethasone vs. betamethasone dosing for lung maturation in fetal sheep
}

\author{
Augusto F. Schmidt ${ }^{1}$, Matthew W. Kemp², Paranthaman S. Kannan ${ }^{1}$, Boris W. Kramer ${ }^{3}$, John P. Newnham², Suhas G. Kallapur \\ and Alan H. Jobe ${ }^{1}$
}

BACKGROUND: Dexamethasone-phosphate $\left(\mathrm{Dex}-\mathrm{PO}_{4}\right)$ and the combination betamethasone-phosphate $\left(\right.$ Beta- $\left.\mathrm{PO}_{4}\right)+$ betamethasone-acetate (Beta-Ac) are the most used antenatal corticosteroids to promote fetal lung maturation. We compared fetal lung maturation induced by Beta-Ac+Beta- $\mathrm{PO}_{4^{\prime}}$ Dex- $\mathrm{PO}_{4^{\prime}}$ or Beta- $\mathrm{PO}_{4}$ alone.

METHODS: Pregnant ewes received two intramuscular doses

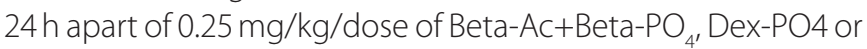
Beta- $\mathrm{PO}_{4}$; or 2 doses of $0.125 \mathrm{mg} / \mathrm{kg} /$ dose of Beta- $\mathrm{PO}_{4}$ at 6,12 , or $24 \mathrm{~h}$ intervals. Fetuses were delivered $48 \mathrm{~h}$ after the first dose and ventilated for $30 \mathrm{~min}$. We assessed ventilatory variables, vital signs, and blood gas. After ventilation pressure-volume curves were measured and lungs were sampled for analysis.

RESULTS: All treatments improved lung compliance and ventilation efficiency. Only Beta-Ac + Beta- $\mathrm{PO}_{4}$ required lower positive inspiratory pressure compared with control. Beta-Ac + Beta- $\mathrm{PO}_{4}$ and Beta- $\mathrm{PO}_{4}$ alone, but not Dex- $\mathrm{PO}_{4}$, increased the mRNA of surfactant proteins compared with control. Low-dose Beta- $\mathrm{PO}_{4}$ did not increase mRNA of surfactant proteins. There were no differences among Beta- $\mathrm{PO}_{4}$ treatment intervals.

CONCLUSION: Beta-Ac + Beta- $\mathrm{PO}_{4}$ given as two doses $24 \mathrm{~h}$ apart was more effective in promoting fetal lung maturation than Dex- $\mathrm{PO}_{4}$ or Beta- $\mathrm{PO}_{4}$ alone, consistent with a prolonged exposure provided by the Beta-Ac + Beta- $\mathrm{PO}_{4}$. These results support the clinical use of combined Beta-Ac + Beta-PO ${ }_{4}$ preparations over phosphate corticosteroids alone for fetal lung maturation.

A ntenatal corticosteroids decrease the incidence of respiratory distress syndrome and other neonatal morbidities in preterm infants and are considered standard of care for women at risk of preterm delivery (1). Despite widespread clinical use there is minimal experimental evidence regarding the formulation or dosing regimen, thus multiple different treatments are used worldwide (2).

Dexamethasone and betamethasone are the fluorinated steroids most commonly used for maternal treatment (2). Dexamethasone phosphate $\left(\mathrm{Dex}-\mathrm{PO}_{4}\right)$ is a short acting glucocorticoid usually given in four doses of $6 \mathrm{mg}$ each, $12 \mathrm{~h}$ apart, for a total dose of $24 \mathrm{mg}$, but other dosing regimens are also frequently used such as two doses of $12 \mathrm{mg}, 24 \mathrm{~h}$ apart. Betamethasone is usually given as a combination of equal parts betamethasone phosphate $\left(\right.$ Beta- $\left.\mathrm{PO}_{4}\right)$ and betamethasone acetate (Beta-Ac) in two doses $24 \mathrm{~h}$ apart of $12 \mathrm{mg}$ each for a total dose of $24 \mathrm{mg}$. Beta- $\mathrm{PO}_{4}$ has a short biological half-life, similar to Dex- $\mathrm{PO}_{4}$, while Beta-Ac is a slow-release suspension with a longer half-life $(3,4)$. In clinical practice, different formulations, such as Beta- $\mathrm{PO}_{4}$ alone, and dosing intervals are used despite limited data from animal or human studies $(1,4)$.

A meta-analysis of the clinical trials comparing dexamethasone to betamethasone showed no difference in respiratory distress syndrome or neonatal mortality, but a decreased incidence of intraventricular hemorrhage (IVH) with Dex- $\mathrm{PO}_{4}$, mostly influenced by the trial from Elimian et al. $(4,5)$. Subtil et al. compared the combination of Beta- $\mathrm{PO}_{4}+$ Beta-Ac to Beta- $\mathrm{PO}_{4}$ alone in 69 infants and observed no difference in the outcomes of neonatal death, respiratory distress syndrome, or IVH (6). A large randomized controlled trial of betamethasone combination drug vs. dexamethasone using a 2 dose $12 \mathrm{mg}$ and 24-h treatment interval with long term follow up is currently underway in Australia (7).

A recent trial of antenatal corticosteroids using Dex- $\mathrm{PO}_{4}$ in low resource environments including almost 100,000 livebirths found no benefit for small infants but increased mortality for large infants exposed to prenatal Dex- $\mathrm{PO}_{4}$ (8). The ability to distinguish between treatment responses to different corticosteroids, doses, and treatment intervals is impractical given the number of variables and large number of patients needed for multiple trials. The sheep model of preterm birth and lung maturation allows the analysis of gas exchange and ventilatory variables in a stage of lung development similar to preterm newborns (9). To provide guidance about maturation responses we compared the fetal lung maturation from clinically used doses of antenatal Beta- $\mathrm{PO}_{4}+$ Beta-Ac to Dex $-\mathrm{PO}_{4}$ or Beta- $\mathrm{PO}_{4}$ alone, as well as a lower dose of Beta- $\mathrm{PO}_{4}$ alone with different dosing intervals, in preterm sheep. 


\section{METHODS}

\section{Antenatal Corticosteroid Treatments}

The animal ethics committee of The University of Western Australia approved the animal studies (RA/3/100/1378). All animals received an i.m. injection of $150 \mathrm{mg}$ medroxyprogesterone acetate (DepoProvera, Pfizer, New York, NY) at $115 \pm 1 \mathrm{~d}$ gestation to decrease the risk of steroid-induced premature labor. Time-mated Merino ewes with singleton fetuses received maternal i.m. injections based on maternal weight of normal saline or corticosteroid treatments with the first dose given on $120 \pm 1 \mathrm{~d}$ of gestation ( $80 \%$ of gestation, term $=150 \mathrm{~d}$ ). A composite group of control ewes received two doses of normal saline i.m. 6, 12, or $24 \mathrm{~h}$ apart. Treatment groups received: two doses of Beta- $\mathrm{PO}_{4}+$ Beta-Ac (Celestone Chronodose, Merck Sharp \& Dohme, Australia) $0.25 \mathrm{mg} / \mathrm{kg} /$ dose i.m. $24 \mathrm{~h}$ apart; two doses of Dex- $\mathrm{PO}_{4}$ (DBL Dexamethasone sodium phosphate, Hospira NZ, New Zealand) $0.25 \mathrm{mg} / \mathrm{kg} /$ dose i.m. $24 \mathrm{~h}$ apart; two doses of Beta- $\mathrm{PO}_{4}$ (Betnesol, Focus Pharmaceuticals, UK) $0.25 \mathrm{mg} / \mathrm{kg} / \mathrm{dose}$ i.m. $24 \mathrm{~h}$ apart. Other groups received two doses of Beta- $\mathrm{PO}_{4} 0.125 \mathrm{mg} / \mathrm{kg} / \mathrm{dose}$ i.m. 6,12 , or $24 \mathrm{~h}$ apart. We adopted the standard dose of $0.25 \mathrm{mg} / \mathrm{kg} /$ dose of Beta- $\mathrm{PO}_{4}+$ Beta-Ac to maintain dosing regimens comparable with previous studies from our group. All animals were delivered $48 \mathrm{~h}$ after the first i.m. injection at $122 \pm 1 \mathrm{~d}$ of gestation.

\section{Ventilatory Assessment}

For delivery pregnant ewes received i.v. midazolam $(0.5 \mathrm{mg} / \mathrm{kg})$ and ketamine $(10 \mathrm{mg} / \mathrm{kg})$ for sedation. Then, $3 \mathrm{ml}$ of $2 \%(20 \mathrm{mg} / \mathrm{ml})$ lidocaine was given for spinal anesthesia for delivery of the fetus. The head of the fetus was delivered through abdominal and uterine incisions and the fetal skin over the trachea was infiltrated with lidocaine. A $4 \mathrm{~mm}$ endotracheal tube was secured by tracheostomy. After delivery of the fetus the ewe was killed with pentobarbital. The lamb was weighed and dried, and temperature maintained with a radiant warmer (Cozy Cot, Fisher \& Paykel Healthcare, New Zealand) and a plastic cover (Neowrap, Fisher \& Paykel, NZ). Mechanical ventilation (Fabian HFO, Accutronic Medical Systems AG, Switzerland) was immediately started with the following settings: peak inspiratory pressure (PIP) of $40 \mathrm{cmH}_{2} \mathrm{O}$, positive end expiratory pressure (PEEP) of $5 \mathrm{cmH}_{2} \mathrm{O}$, respiratory rate of 50 breaths per minute, inspiratory time of $0.6 \mathrm{~s}$, and $100 \%$ heated and humidified oxygen. The standard use of $100 \%$ oxygen allows the comparison of oxygenation trough the partial arterial pressure of oxygen among the groups. The umbilical artery was catheterized for blood sampling and administration of supplemental anesthesia with ketamine $(5 \mathrm{mg} / \mathrm{kg})$ if necessary. The tidal volume $\left(\mathrm{V}_{\mathrm{T}}\right)$ was continuously measured and the PIP was adjusted to keep the $\mathrm{V}_{\mathrm{T}}$ between 8.5 and $9.5 \mathrm{ml} / \mathrm{kg}$ but with a maximal pressure limited of $40 \mathrm{cmH}_{2} \mathrm{O}$. At 10,20 , and $30 \mathrm{~min}$ of ventilation we measured temperature, blood pressure, ventilator data (PIP, $V_{T}$, and compliance), and performed blood gas measurements. Dynamic compliance was recorded as measured by the ventilator. The ventilation efficiency index (VEI) was calculated using the formula VEI = $3,800 /\left(\right.$ respiratory rate $\left.(\mathrm{PIP}-\mathrm{PEEP}) \times \mathrm{PCo}_{2}(\mathrm{~mm} \mathrm{Hg})\right)$.

\section{Lung Assessment}

After ventilation for $30 \mathrm{~min}$ lambs were disconnected from the ventilator and the endotracheal tube was clamped for $2 \mathrm{~min}$ to achieve atelectasis by oxygen absorption. The lambs received a lethal dose of pentobarbital, were weighed and the chest was opened for visual evaluation of gross lung injury-pulmonary hemorrhage, pulmonary interstitial emphysema, gas pockets within the lung or subpleural dissection-performed by the same investigator. A deflation pressure-volume curve was measured after air inflation of the lungs to a pressure of $40 \mathrm{cmH}_{2} \mathrm{O}$ (8).

\section{Quantitation of mRNA}

Total RNA was isolated from frozen lungs after homogenization with TRIzol (Invitrogen, Carlsbad, CA). Reverse transcription was performed using Verso cDNA kit (Thermo Scientific, Waltham, MA) to produce single-strand CDNA. The genes for surfactant protein A (SPA), surfactant protein B (SPB), surfactant protein C (SPC), surfactant protein D (SPD), ATP-binding cassette subfamily A member 3 (ABCA3)--expressed by type 2 alveolar cells, and aquaporin 5 (AQP5) - expressed by type 1 alveolar cells, were amplified using the cDNA template and sheep-specific primers along with Taqman probes (Applied Biosystems, Foster City, CA). The mRNA expression for each gene was normalized to the mRNA for the ribosomal protein $18 \mathrm{~s}$ as internal standard. Final data are expressed as fold increase over the control value.

\section{Statistical Analysis}

Data are presented as mean \pm SEM. Statistical tests were performed with Prism software 6.0 (GraphPad Software, San Diego, CA). Initial comparisons were performed with ANOVA followed by multiple groups comparison with Tukey's post-hoc test, with separate ANOVA tests performed for the comparison among Beta- $\mathrm{PO}_{4}+$ Beta-Ac, Dex- $\mathrm{PO}_{4}$, and Beta- $\mathrm{PO}_{4}$ alone, among Beta- $\mathrm{PO}_{4}+$ Beta-Ac, standard and low dose Beta- $\mathrm{PO}_{4}$, and among the low-dose Beta- $\mathrm{PO}_{4}$ intervals. Selected group comparisons were performed by $t$-tests where appropriate and are indicated in the results section. Significance was attributed for P-values $<0.05$.

\section{RESULTS \\ Delivery Data and Animals}

The number of animals, weights, sex distribution, and cord blood gas values are given in Table 1 . The group means for birth weight were lower for animals that received Beta- $\mathrm{PO}_{4}$

Table 1. Summary of animals and delivery data

\begin{tabular}{|c|c|c|c|c|c|c|c|}
\hline & \multirow{2}{*}{$\begin{array}{c}\text { Negative control } \\
\text { Saline }\end{array}$} & \multirow{2}{*}{$\begin{array}{c}\text { Positive control } \\
\text { Beta-PO }+ \text { BetaAc } \\
0.25 \mathrm{mg} / \mathrm{kg} \times 224 \mathrm{~h}\end{array}$} & \multicolumn{2}{|c|}{ Dex- $-\mathrm{PO}_{4}$ vs. Beta- $\mathrm{PO}_{4}$} & \multicolumn{3}{|c|}{$\begin{array}{l}\text { Beta- } \mathrm{PO}_{4} \text { dosing interval } \\
\text { Beta- } \mathrm{PO}_{4} 0.125 \mathrm{mg} / \mathrm{kg} \times 2\end{array}$} \\
\hline & & & $\begin{array}{c}\mathrm{Dex}^{-\mathrm{PO}_{4}} \\
0.25 \mathrm{mg} / \mathrm{kg} \times 224 \mathrm{~h}\end{array}$ & $\begin{array}{c}\text { Beta- } \mathrm{PO}_{4} \\
0.25 \mathrm{mg} / \mathrm{kg} \times 224 \mathrm{~h}\end{array}$ & $6 \mathrm{~h}$ & $12 \mathrm{~h}$ & $24 \mathrm{~h}$ \\
\hline Gestational age & $122 \pm 0.7$ & $122 \pm 0.7$ & $122 \pm 1.0$ & $122 \pm 1.0$ & $122 \pm 0.7$ & $121 \pm 0.5$ & $122 \pm 0.5$ \\
\hline Weight & $2.9 \pm 0.3$ & $2.8 \pm 0.4$ & $2.6 \pm 0.5$ & $2.6 \pm 0.2^{*}$ & $2.6 \pm 0.2^{*}$ & $2.5 \pm 0.4^{*}$ & $2.6 \pm 0.3^{*}$ \\
\hline \multicolumn{8}{|l|}{ Sex } \\
\hline Male / Female & $7 / 4$ & $4 / 5$ & $7 / 3$ & $5 / 5$ & $2 / 8$ & $5 / 5$ & $4 / 6$ \\
\hline \multicolumn{8}{|l|}{ Cord gas } \\
\hline $\mathrm{pH}$ & $7.36 \pm 0.05$ & $7.36 \pm 0.05$ & $7.37 \pm 0.04$ & $7.33 \pm 0.05$ & $7.28 \pm 0.14$ & $7.34 \pm 0.02$ & $7.35 \pm 0.04$ \\
\hline $\mathrm{pCO}_{2}(\mathrm{mmHg})$ & $51 \pm 9$ & $53 \pm 6$ & $48 \pm 4$ & $48 \pm 2$ & $60 \pm 21$ & $47 \pm 4$ & $51 \pm 4$ \\
\hline
\end{tabular}




\section{Articles | Schmidt et al.}

$(P<0.05)$. There were no differences between the birth weights of animals that received Beta- $\mathrm{PO}_{4}+$ Beta-Ac or Dex-PO $\mathrm{Com}$ pared with controls. One animal, which received two doses of $0.25 \mathrm{mg} / \mathrm{kg}$ of Beta- $\mathrm{PO}_{4}$ alone delivered prematurely and was excluded from the analysis. Two other animals in this group were in preterm labor with bulging membranes on the day of delivery. The cord blood gas measurements were similar between the groups.

\section{Dexamethasone vs. Betamethasone $0.25 \mathrm{mg} / \mathrm{kg}$}

Vital signs, ventilatory results, and injury. Table 2 gives the blood pressures, blood gas measurements, and ventilator data

Table 2. Vital signs and ventilatory data at 30 min of ventilation

\begin{tabular}{|c|c|c|c|c|c|c|c|}
\hline & \multirow{3}{*}{$\begin{array}{c}\text { Negative control } \\
\text { Saline }\end{array}$} & \multirow{3}{*}{$\begin{array}{c}\text { Positive control } \\
\text { Beta-PO }+ \text { Beta AC } \\
0.25 \mathrm{mg} / \mathrm{kg} \times 224 \mathrm{~h}\end{array}$} & \multicolumn{2}{|c|}{ Dex- $-\mathrm{PO}_{4}$ vs. Beta- $\mathrm{PO}_{4}$} & \multirow{2}{*}{\multicolumn{3}{|c|}{$\begin{array}{l}\text { Beta- } \mathrm{PO}_{4} \text { dosing interval } \\
\text { Beta- } \mathrm{PO}_{4} 0.125 \mathrm{mg} / \mathrm{kg} \times 2\end{array}$}} \\
\hline & & & \multirow{2}{*}{$\begin{array}{c}{\text { Dex }-\mathrm{PO}_{4}} \\
0.25 \mathrm{mg} / \mathrm{kg} \times 224 \mathrm{~h}\end{array}$} & \multirow{2}{*}{$\begin{array}{c}\text { Beta- } \mathrm{PO}_{4} \\
0.25 \mathrm{mg} / \mathrm{kg} \times 224 \mathrm{~h}\end{array}$} & & & \\
\hline & & & & & $6 \mathrm{~h}$ & $12 \mathrm{~h}$ & $24 \mathrm{~h}$ \\
\hline \multicolumn{8}{|l|}{ Blood pressure } \\
\hline $\mathrm{SBP}(\mathrm{mmHg})$ & $74 \pm 9.4$ & $82 \pm 8.9^{*}$ & $75 \pm 6.4$ & $84 \pm 15.6^{*}$ & $74 \pm 9.4$ & $76 \pm 10.9$ & $77 \pm 11.4$ \\
\hline $\mathrm{DBP}(\mathrm{mmHg})$ & $40 \pm 6.6$ & $49 \pm 9.6^{*}$ & $44 \pm 5.0$ & $50 \pm 8.5^{*}$ & $41 \pm 5.9$ & $45 \pm 8.1^{*}$ & $47 \pm 12.3^{*}$ \\
\hline \multicolumn{8}{|c|}{ Blood gas values - $30 \mathrm{~min}$} \\
\hline $\mathrm{pH}$ & $7.02 \pm 0.1$ & $7.23 \pm 0.14^{*}$ & $7.19 \pm 0.08^{*}$ & $7.13 \pm 0.10^{*}$ & $7.16 \pm 0.09 *$ & $7.17 \pm 0.08^{*}$ & $7.18 \pm 0.11^{*}$ \\
\hline $\mathrm{pCO}_{2}(\mathrm{mmHg})$ & $93 \pm 17$ & $57 \pm 15^{*}$ & $64 \pm 9.4^{*}$ & $66.7 \pm 12.4^{*}$ & $69 \pm 13^{*}$ & $64 \pm 11^{*}$ & $63 \pm 7.8^{*}$ \\
\hline $\mathrm{pO}_{2}(\mathrm{mmHg})$ & $53 \pm 45$ & $64 \pm 40$ & $152 \pm 65^{*}$ & $79 \pm 62$ & $121 \pm 57^{*}$ & $119 \pm 61^{*}$ & $106 \pm 67$ \\
\hline \multicolumn{8}{|c|}{ Ventilation values - $30 \mathrm{~min}$} \\
\hline $\mathrm{PIP}\left(\mathrm{cmH}_{2} \mathrm{O}\right)$ & $37 \pm 6.4$ & $32 \pm 5.9^{*}$ & $36 \pm 2.6$ & $34 \pm 4.8$ & $36 \pm 5.0$ & $35 \pm 4.8$ & $35 \pm 4.8$ \\
\hline $\mathrm{V}_{\mathrm{T}}(\mathrm{ml} / \mathrm{kg})$ & $6.8 \pm 1.3$ & $8.2 \pm 0.8$ & $8.6 \pm 0.4$ & $8.7 \pm 2.1$ & $8.7 \pm 0.5$ & $8.7 \pm 0.5$ & $8.2 \pm 0.9$ \\
\hline Lung injury n (\%) & $3(27 \%)$ & $1(11 \%)$ & $4(44 \%)$ & $2(20 \%)$ & $2(20 \%)$ & $2(20 \%)$ & $1(10 \%)$ \\
\hline
\end{tabular}

DBP, diastolic blood pressure; Lung injury, pulmonary blebs, hemorrhage, or air leak; SBP, systolic blood pressure; PIP, peak inspiratory pressure; $V_{T}$, tidal volume. ${ }^{*} P<0.05$ compared with control.

a

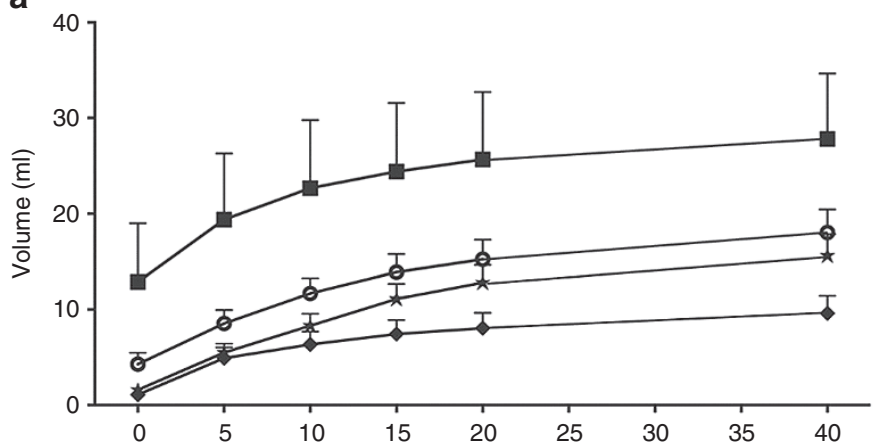

C

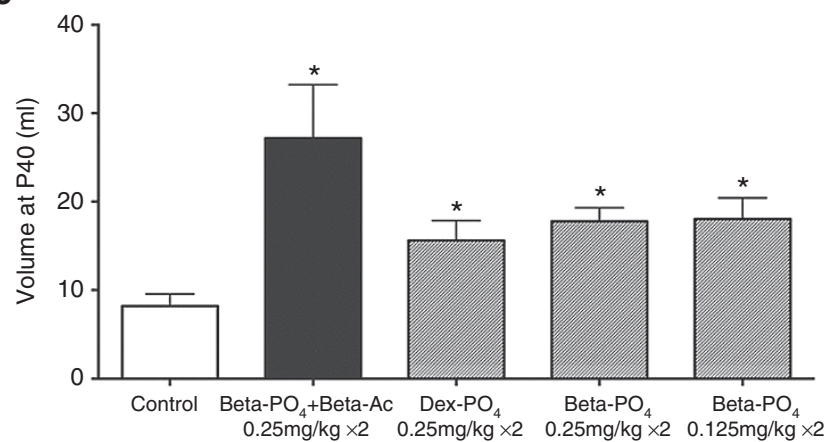

b

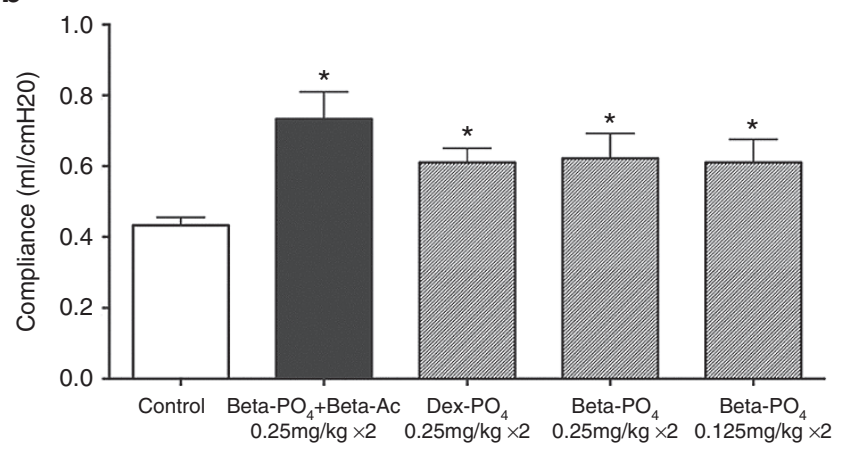

d

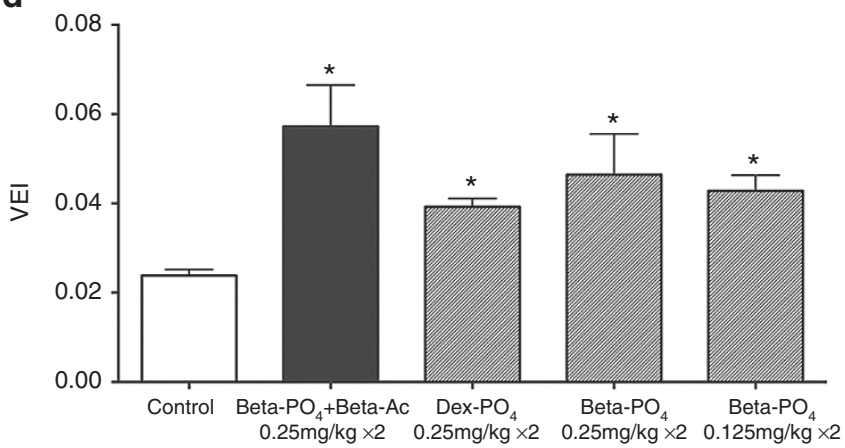

Figure 1. Physiological data after 30 min of ventilation. (a) Pressure volume curves: Deflation limbs of pressure-volume curves after $30 \mathrm{~min}$ of ventilation

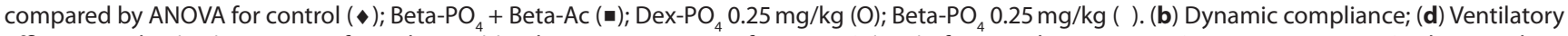
efficiency index (VEI) at $30 \mathrm{~min}$ of ventilation; (c) Volume at a pressure of $40 \mathrm{cmH}_{2} \mathrm{O}$ (V40) after ventilation. Beta-PO + Beta-Ac, Beta-PO alone, and Dex- $\mathrm{PO}_{4}$ improved all ventilator parameters compared with control. Standard and low-dose Beta- $\mathrm{PO}_{4}$ resulted in similar improvements in lung compliance and VEI ( $\left.{ }^{*} P<0.05\right)$. Beta- $\mathrm{PO}_{4^{\prime}}$, betamethasone-phosphate; Beta-Ac, betamethasone-acetate; Dex-PO ${ }_{4^{\prime}}$ Dexamethasone-phosphate. 
at $30 \mathrm{~min}$ of ventilation. The diastolic, systolic, and mean blood pressures were higher in the animals treated with Beta- $\mathrm{PO}_{4}$ + Beta-Ac or Beta- $\mathrm{PO}_{4}$ alone compared with controls, while only the mean blood pressure was higher in animals exposed to Dex- $\mathrm{PO}_{4}$ compared with controls $(P<0.05)$. The mean $\mathrm{pH}$ values were higher and the mean $\mathrm{pCO}_{2}$ values were lower in the three groups compared with controls at $30 \mathrm{~min}$ of ventilation $(P<0.05)$. Animals treated with Beta- $\mathrm{PO}_{4}+\mathrm{Beta}-\mathrm{Ac}$ had PIP at 30 min significantly lower than control $(P<0.05)$, while animals treated with Beta- $\mathrm{PO}_{4}$ alone or Dex- $\mathrm{PO}_{4}$ had PIP at 30 min similar to control.

Dynamic compliance, VEI and lung gas volume at 40 $\mathrm{cmH}_{2} \mathrm{O}$ was higher in animals treated with Beta- $\mathrm{PO}_{4}+$ Beta-Ac, Beta- $\mathrm{PO}_{4}$ alone, or Dex- $\mathrm{PO}_{4}$ than the control animals $(P<0.05$, Figure 1). There was no statistical difference in these variables among animals that received Beta- $\mathrm{PO}_{4}+$ Beta-Ac compared with Beta- $\mathrm{PO}_{4}$ alone and $\mathrm{Dex}-\mathrm{PO}_{4}$ (Figure 1). By $t$-test comparison between Beta- $\mathrm{PO}_{4}+$ Beta-Ac and Dex- $\mathrm{PO}_{4}$ there was a nonsignificant trend toward better volume at 40 $\mathrm{cmH}_{2} \mathrm{O}$ and VEI in the Beta- $\mathrm{PO}_{4}+$ Beta-Ac group $(P=0.09)$.

Gross lung injury-subpleural air dissection, hemorrhage, or air leak-was observed in three control animals (27\%, two animals with hemorrhage and one with air leak) and four animals that received Dex- $\mathrm{PO}_{4}(44 \%$, two animals with air leak and two animals with subpleural dissection) but in only one animal treated with Beta- $\mathrm{PO}_{4}+\mathrm{Beta}-\mathrm{Ac}$ (11\%, subpleural dissection).

\section{mRNA Quantitation}

Figure 2 gives the relative mRNA quantitation for the surfactant proteins, $\mathrm{ABCA} 3$, and $\mathrm{AQP} 5$ and statistical significance by ANOVA. Beta- $\mathrm{PO}_{4}+$ Beta-Ac and Beta- $\mathrm{PO}_{4}$ alone significantly increased the mRNA level for SPA, SPB, SPC, and ABCA3 ( $P$ $<0.05)$. Only Beta- $\mathrm{PO}_{4}+$ Beta-Ac significantly increased the mRNA level of SPD $(P<0.05)$. Dex- $\mathrm{PO}_{4}$ did not significantly increase the mRNA levels of the surfactant proteins or ABCA3. Beta- $\mathrm{PO}_{4}+$ Beta-Ac, Beta- $\mathrm{PO}_{4}$ alone, and Dex- $\mathrm{PO}_{4}$ increased the mRNA levels of AQP5 compared with control $(P<0.05)$.

\section{Beta-PO4 $0.125 \mathrm{mg} / \mathrm{kg} \times 2$ vs. Beta-PO4 $0.25 \mathrm{mg} / \mathrm{kg} \times 2$}

Vital signs, ventilator results, and injury. Lambs treated with either the standard $(0.25 \mathrm{mg} / \mathrm{kg} \times 2)$ or the low-dose $(0.125 \mathrm{mg} /$ $\mathrm{kg} \times 2)$ Beta- $\mathrm{PO}_{4}$ given $24 \mathrm{~h}$ apart had increased diastolic and mean blood pressure, higher $\mathrm{pH}$ and lower $\mathrm{pCO}_{2}$ compared with control animals (Table 2$)(P<0.05)$. There were no vital signs differences between the standard dose and the low-dose group. There was no difference in $\mathrm{V}_{\mathrm{T}}$, PIP, or frequency in lung injury among groups.

Dynamic compliance, VEI and volume at $40 \mathrm{cmH}_{2} \mathrm{O}$ were higher in animals treated with Beta- $\mathrm{PO}_{4}$ either standard or low-dose compared with controls $(P<0.05$, Figure 1$)$. On select $t$-test comparison between the standard and low-dose Beta- $\mathrm{PO}_{4}$ there were no differences in those variables.

\section{mRNA quantitation}

While the standard dose of Beta- $\mathrm{PO}_{4}$ increased the mRNA expression of SPA, SPB, SPC, AQP5, and ABCA3, low-dose
Beta- $\mathrm{PO}_{4}$ only significantly increased the mRNA expression of AQP5 by ANOVA (Figure 2). However, $t$-test comparison of mRNA expression between the standard and low-dose showed no differences between the groups for expression of the biochemical markers of lung maturation.

\section{Low-dose Betamethasone treatment intervals}

Vital signs, ventilatory results, and injury. Lambs treated with low-dose Beta- $\mathrm{PO}_{4}$ alone at 12 and $24 \mathrm{~h}$ intervals, but not at 6-h intervals, had higher diastolic and mean blood pressures compared with controls (Table 2) $(P<0.05)$. All groups exposed to low-dose Beta- $\mathrm{PO}_{4}$ had higher $\mathrm{pH}$ and lower $\mathrm{pCO}_{2}$ at $30 \mathrm{~min}$ of ventilation compared with controls $(P<0.05)$, and those values were similar among the treated groups. There was no difference in the ventilation variables compared with the control group. (Table 2)

Dynamic compliance, VEI and volume at $40 \mathrm{cmH}_{2} \mathrm{O}$ were higher in animals treated with Beta- $\mathrm{PO}_{4}+$ Beta-Ac and low-dose Beta- $\mathrm{PO}_{4}$ alone compared with controls $(P<0.05$, Figure 3). Even though the mean for these variables were higher in animals that received Beta- $\mathrm{PO}_{4}+$ Beta-Ac compared with low-dose Beta- $\mathrm{PO}_{4}$ alone, the difference was not statistically significant. (Figure 3 ).

In the 6 and $12 \mathrm{~h}$ dosing interval groups two animals in each group (20\%) had gross lung injury (one animal with air leak and one with subpleural dissection in each group) while only one of the animals in the $24 \mathrm{~h}$ dosing group (petechiae) had lung injury compared with one animal (11\%) on the Beta- $\mathrm{PO}_{4}$ + Beta-Ac group and three (27\%) of the animals in the control group. The differences among groups were not statistically significant.

\section{mRNA Quantitation}

Figure 4 gives the relative mRNA quantitation for the surfactant proteins, $\mathrm{ABCA} 3$ and $\mathrm{AQP} 5$ and also statistical significance by ANOVA. Low dose Beta- $\mathrm{PO}_{4}$ at 6-h interval, but not at 12 or 24 -h intervals, significantly increased the mRNA of SPA and SPD compared with controls $(P<0.05)$. Low-dose Beta- $\mathrm{PO}_{4}$ at any dosing interval did not significantly change the expression of SPB, SPC, SPD, or ABCA3. Low-dose Beta- $\mathrm{PO}_{4}$ at 24 -h interval, but not at 6 or $12-\mathrm{h}$ intervals, increased the expression of AQP5 $(P<0.05)$.

\section{DISCUSSION}

We identified differences among clinically used corticosteroid formulations in promoting fetal lung maturation. Specifically we report the new findings that betamethasone formulations are superior to dexamethasone in increasing the mRNA expression of surfactant proteins. Despite the lack of statistical significance in lung mechanics among the formulations tested with a small number of animals per group the trend toward higher dynamic compliance, volume at $40 \mathrm{cmH}_{2} \mathrm{O}$, and VEI in animals exposed to Beta- $\mathrm{PO}_{4}+$ Beta-Ac could be biologically relevant in preventing need to for mechanical ventilation and lung injury, especially considering the need for lower PIP in this group. 


\section{Articles | Schmidt et al.}
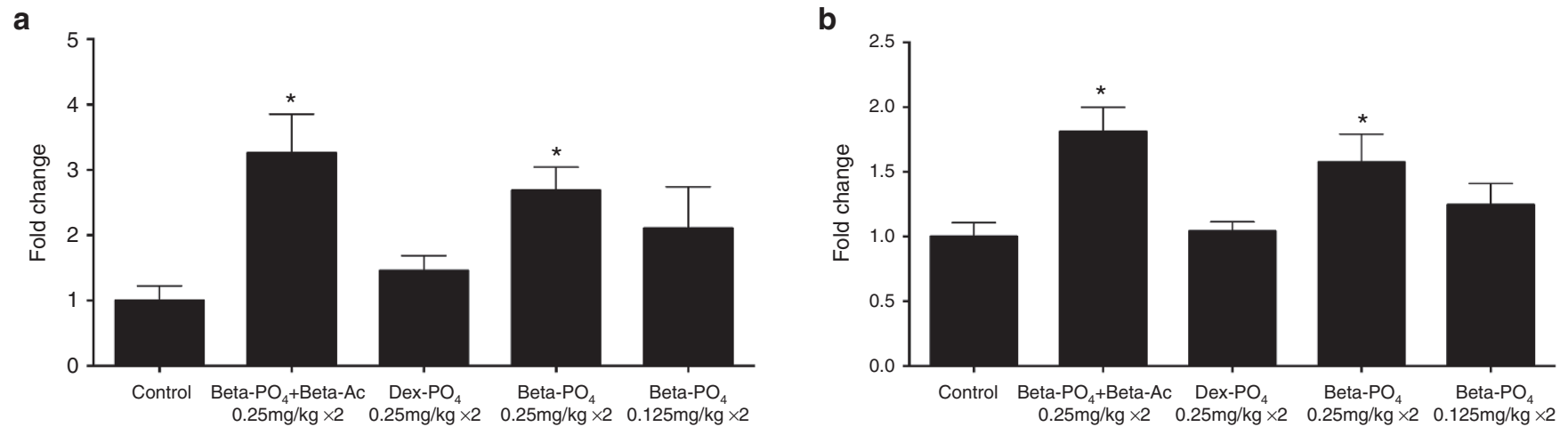

C

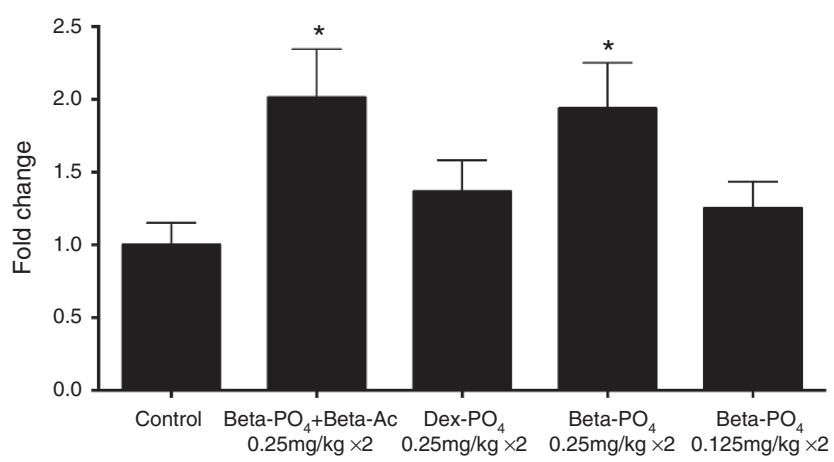

d

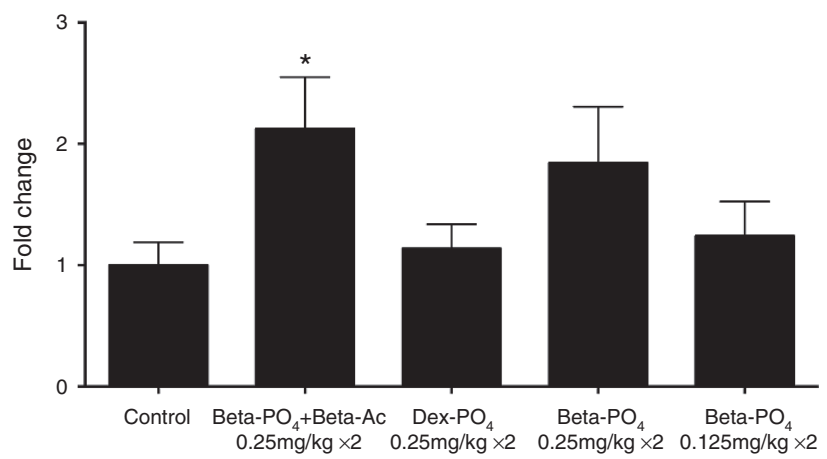

e

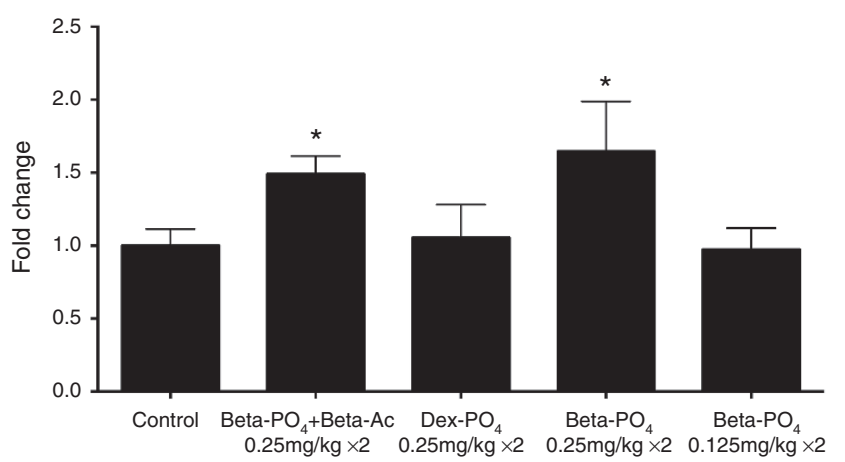

f

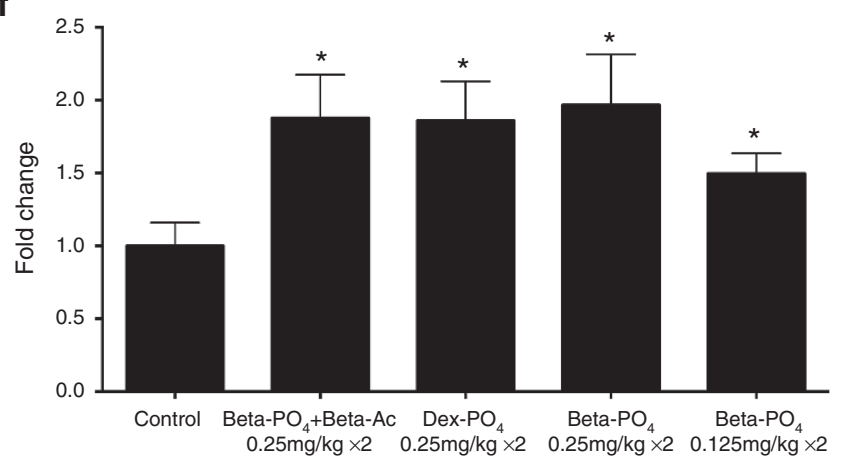

Figure 2. mRNA quantitation in fold change relative to control compared by ANOVA for (a) surfactant protein $A$ (SPA); (b) surfactant protein $B$ (SPB); (c) surfactant protein C (SPC); (d) surfactant protein D (SPD); (e) ATP-binding cassette family A member 3 (ABCA3); (f) Aquaporin 5 (AQP5). Beta-PO ${ }_{4}+$ Beta-Ac or Beta-PO alone significantly increased the expression of SPA, SPB, SPC, and ABCA3 $(P<0.05)$. Only Beta-PO + Beta-Ac significantly increased the expression of SPD $(P<0.05)$. Beta- $\mathrm{PO}_{4}+$ Beta-Ac, Beta- $\mathrm{PO}_{4}$ alone, and Dex-PO increased the expression of AQP5 $(P<0.05)$. Dexamethasone did not significantly change the expression of any surfactant proteins or $\mathrm{ABCA3}$. Low-dose Beta-PO $\mathrm{P}_{4}$ only increased mRNA expression $\mathrm{AQP} 5$ at $24 \mathrm{~h}$ interval $(P<0.05)$.

Clinical studies did not identify consistent differences in the outcomes of preterm newborns treated antenatally with dexamethasone compared with betamethasone (2). In our study, even though dexamethasone improved dynamic lung compliance and VEI comparable to Betamethasone (Figure 1), lambs that received Beta- $\mathrm{PO}_{4}+$ Beta-Ac required significantly lower PIPs after $30 \mathrm{~min}$ of ventilation (Table 2). In preterm lambs, ventilation with a $V_{T}$ of $8 \mathrm{ml} / \mathrm{kg}$ increases markers of lung injury (10). Therefore the decreased pressure requirement with Beta- $\mathrm{PO}_{4}+$ Beta-Ac treatment may be relevant in preventing lung injury in ventilated preterm infants. In our study the dexamethasone group had the highest number of animals with signs of gross lung injury (44\%). Treatment with two doses of $0.25 \mathrm{mg} / \mathrm{kg}$ of Beta- $\mathrm{PO}_{4}$ alone resulted in improvements in the dynamic lung compliance and VEI comparable to dexamethasone and tended to be lower than Beta- $\mathrm{PO}_{4}+$ Beta-Ac although the difference was not significant. Similarly to dexamethasone, the PIP requirement in the Beta- $\mathrm{PO}_{4}$ alone group at $30 \mathrm{~min}$ of ventilation to maintain a $\mathrm{V}_{\mathrm{T}}$ of $8.5 \mathrm{ml} / \mathrm{kg}$ was not different from control. Even though $\mathrm{paO}_{2}$ was measured it is not an adequate marker of lung maturation due to the presence of an open ductus arteriosus with variation in size and directions of shunting among animals.

The fact that dexamethasone did not significantly increase the mRNA levels of the surfactant proteins or ABCA3 while a similar total steroid dose of Beta- $\mathrm{PO}_{4}+$ Beta-Ac or Beta- $\mathrm{PO}_{4}$ alone increased the mRNA levels by two to threefold may be of clinical significance. Since the regulation of surfactant proteins 
a

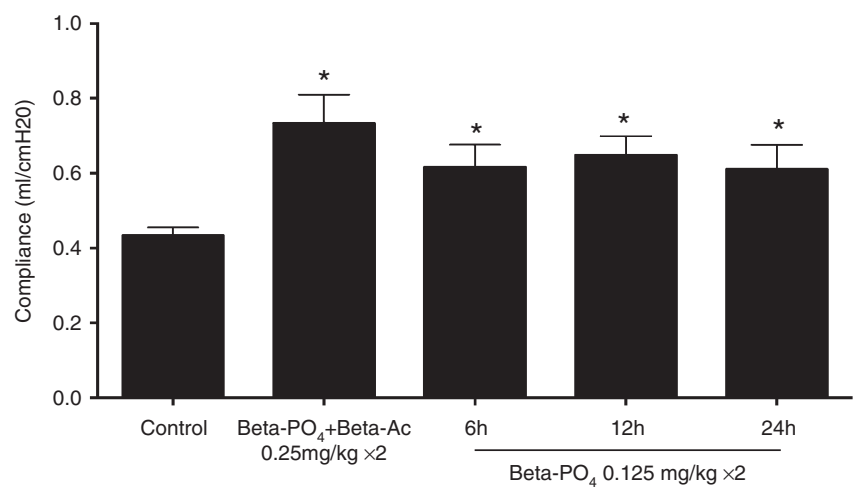

b

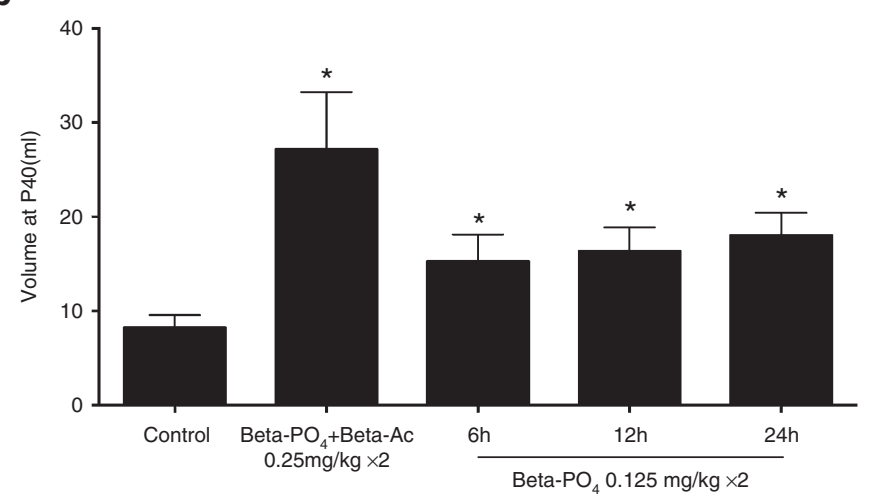

C

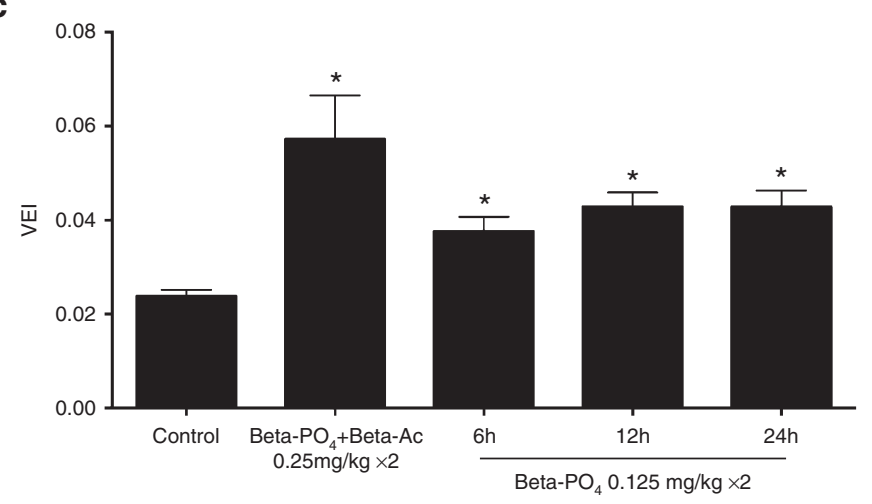

Figure 3. Physiological data after 30 min of ventilation. (a) Dynamic compliance; (b) Ventilatory efficiency index (VEI) at 30 min of ventilation; (c) Volume at a pressure of $40 \mathrm{cmH}_{2} \mathrm{O}(\mathrm{V} 40)$ after ventilation. Comparisons performed by ANOVA with corrected multiple comparisons. Standard and low-dose resulted in similar improvement in lung mechanics $\left({ }^{*} P<0.05\right)$.

$A$ and $B$ is mostly pretranslational (11), the lack of increase in SPA and SPB mRNA by dexamethasone likely results in lower surfactant protein pool compared with treatment with betamethasone and contributes to the higher PIP requirement and trend toward lower dynamic and static compliance and VEI observed with dexamethasone. A similar dose of Beta- $\mathrm{PO}_{4}$ alone resulted in significant increases in the mRNA levels of SPA, SPB, SPC, and ABCA3 to levels similar to those observed with Beta- $\mathrm{PO}_{4}+$ Beta-Ac. This is particularly interesting given the fact that Dex- $-\mathrm{PO}_{4}$ and Beta- $\mathrm{PO}_{4}$ have similar structure and pharmacological properties but different effects on the biochemical maturation of the fetal lung.

Besides inducing lung maturation, glucocorticoids affect multiple systems, which were not evaluated in this study. Studies comparing the side effects of antenatal dexamethasone vs. betamethasone have yielded conflicting results. Animal studies have suggested that antenatal dexamethasone was associated with developmental delay and altered neurobehavioral performance compared with betamethasone (12). In one retrospective study betamethasone has been associated with decreased risk of periventricular leukomalacia among very low birth weight infants (13), while in a randomized trial dexamethasone was associated with decreased incidence of IVH (5). While it is not clear whether one of the formulations is associated with decreased adverse effects, repeated doses have been associated with decreased birth weight (14) and decreased head circumference (15) and are likely not beneficial (16). Hence, limiting exposure to antenatal corticosteroids may prevent adverse growth and neurological outcomes.

Given the safety concerns with repeated exposures, we asked if a lower dose of Beta- $\mathrm{PO}_{4}$ alone that had the same amount of Beta- $\mathrm{PO}_{4}$ as in the Beta- $\mathrm{PO}_{4}+$ Beta-Ac combination would induce similar fetal lung maturation. Previous work has demonstrated that a single dose of 0.5 or $0.25 \mathrm{mg} / \mathrm{kg}$ of Beta- $\mathrm{PO}_{4}$ did not induce fetal lung maturation (17). Hence, we administered a two dose regimen of $0.125 \mathrm{mg} / \mathrm{kg} /$ dose for a total Beta- $\mathrm{PO}_{4}$ dose of $0.25 \mathrm{mg} / \mathrm{kg}$ at different dosing intervals. Low-dose Beta- $\mathrm{PO}_{4}$ given as 2 doses improved dynamic and static lung compliance, and VEI, compared with control. Interestingly, the compliance, VEI and V40 values observed with the low dose Beta- $\mathrm{PO}_{4}$ were essentially the same as the ones observed with the higher dose of Beta- $\mathrm{PO}_{4}$ alone. On the other hand the low dose Beta- $\mathrm{PO}_{4}$ did not change the expression of surfactant proteins at any dosing interval compared with controls. The fact that we observed an improvement in lung static and dynamic compliance without change in the mRNA for surfactant proteins in the low dose Beta- $\mathrm{PO}_{4}$ group suggests that the lung maturation observed during ventilation with the lower doses in our study may be more related to structural lung maturation rather than biochemical changes in surfactant production and tissue water balance.

Pharmacokinetics studies can contribute to our understanding of the differences among glucocorticoid formulations 


\section{Articles | Schmidt et al.}

a

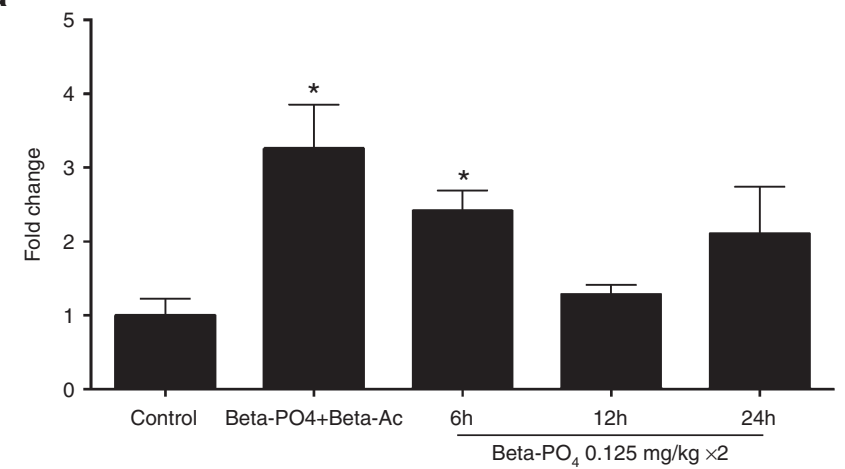

C

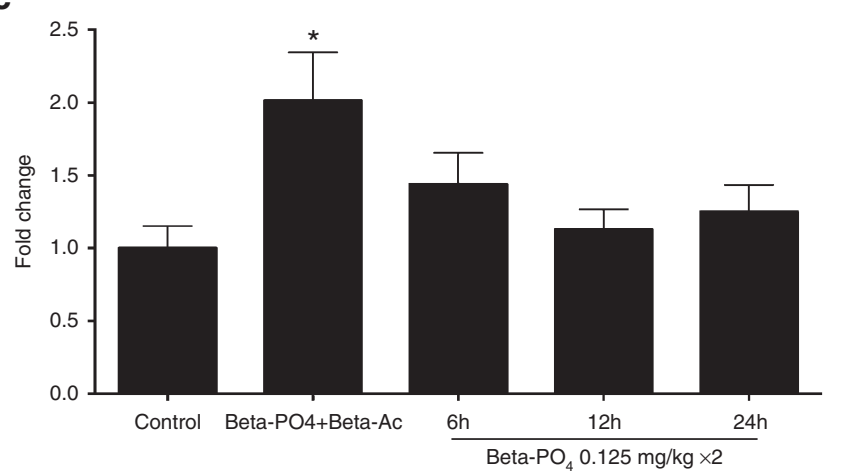

e

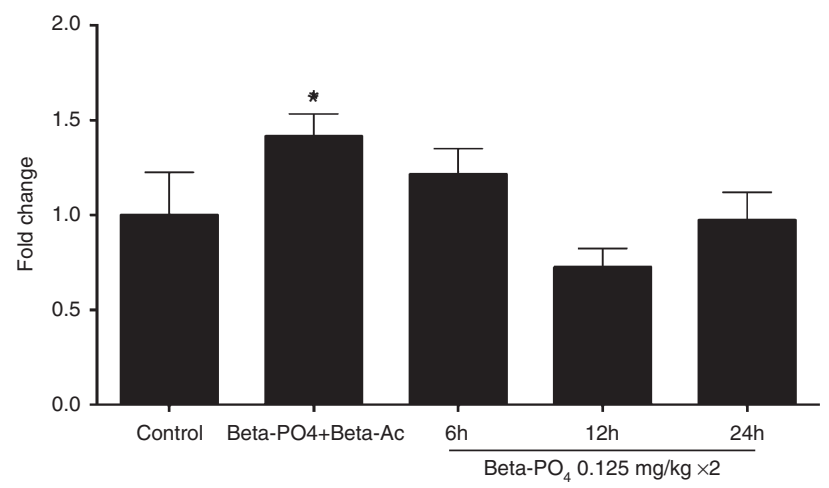

b

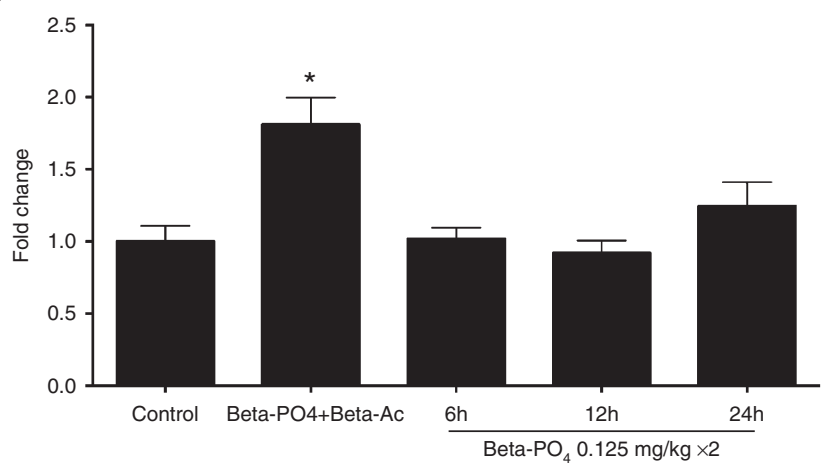

d

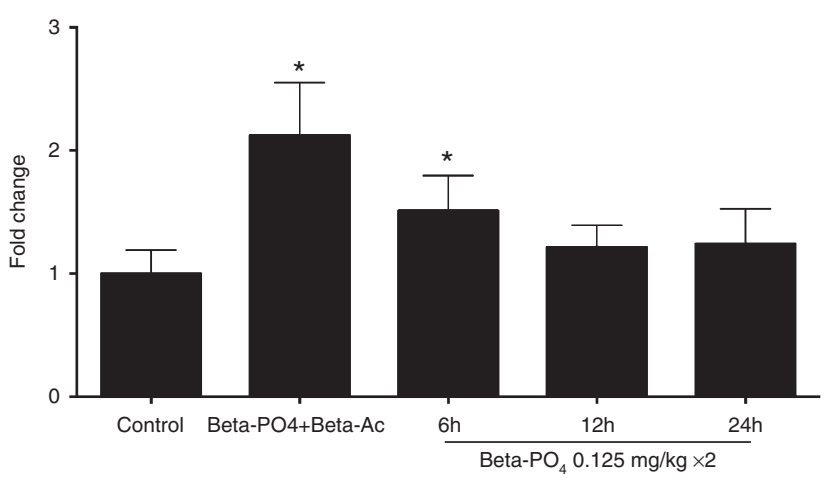

f

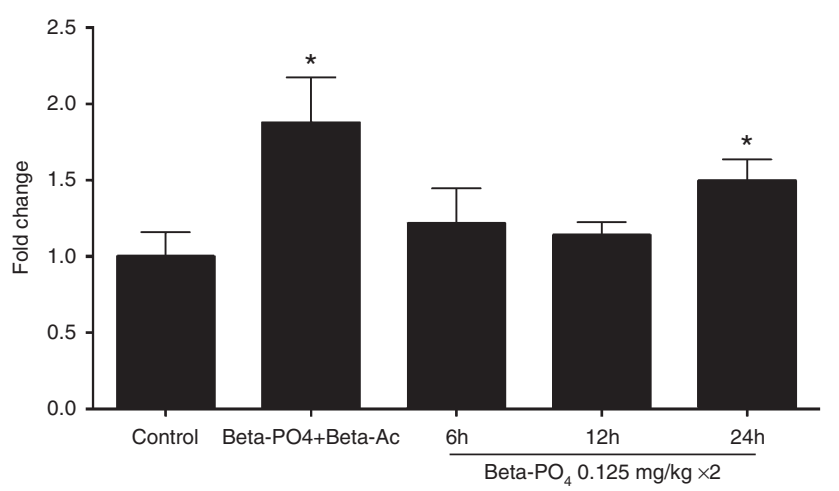

Figure 4. mRNA quantitation in fold change relative to control for (a) surfactant protein $A$ (SPA); (b) surfactant protein $B$ (SPB); (c) surfactant protein $C$ (SPC); (d) surfactant protein D (SPD); (e) ATP-binding cassette family A member 3 (ABCA3); (f) Aquaporin 5 (AQP5). Low-dose Beta-PO alone only changes the expression of SPA at $6 \mathrm{~h}$ interval and expression of AQP5 at $24 \mathrm{~h}$ interval on ANOVA.

in inducing lung maturation. In pregnant sheep, a $0.17 \mathrm{mg} /$ $\mathrm{kg}$ dose of i.m. Beta- $\mathrm{PO}_{4}+$ Beta-Ac or Beta- $\mathrm{PO}_{4}$ result in a fetal plasma peak of $12 \mathrm{ng} / \mathrm{ml}$ at $3-4 \mathrm{~h}$ with detectable betamethasone levels for up to $12 \mathrm{~h}$ (18). In a previous study, we demonstrated that after a single maternal dose of $0.5 \mathrm{mg} / \mathrm{kg}$ of Beta- $\mathrm{PO}_{4}+$ Beta-Ac, the peak of Beta in the fetal plasma is $\sim 15 \mathrm{ng} / \mathrm{ml}$ at $1.5 \mathrm{~h}$ which becomes undetectable after $24 \mathrm{~h}$. On the other hand, a $0.25 \mathrm{mg} / \mathrm{kg}$ i.m. dose of Beta-Ac alone results in a maternal peak of $6-9 \mathrm{~h}$ and very low $(2.4 \mu \mathrm{g} / \mathrm{ml})$ to undetectable fetal levels of Beta (9).

Despite the undetectable fetal levels, a single $0.5 \mathrm{mg} / \mathrm{kg}$ dose of Beta-Ac improves lung compliance and surfactant protein mRNA expression. On the other hand, a single $0.5 \mathrm{mg} /$ $\mathrm{kg}$ dose of Beta- $\mathrm{PO}_{4}$, which produces a higher fetal peak level than Beta-Ac, does not improve lung compliance or surfactant mRNA expression (9). In this study, we demonstrated that two doses of $0.25 \mathrm{mg} / \mathrm{kg}$ of either Beta- $\mathrm{PO}_{4}$ or Dex $-\mathrm{PO}_{4}$ improves lung compliance, albeit not to the same degree as the Beta- $\mathrm{PO}_{4}$ + Beta-Ac formulation, and are less effective in increased surfactant mRNA expression. These data suggest that a lower and prolonged fetal exposure to corticosteroids is more effective in inducing fetal lung maturation than higher peaks with a shorter exposure. This strategy may also result in a decreased total dose of antenatal corticosteroids, thereby limiting possible side effects.

In summary, the combination of Beta- $\mathrm{PO}_{4}+$ Beta-Ac was superior to $\mathrm{DexPO}$ or Beta- $\mathrm{PO}_{4}$ alone at promoting biochemi$\mathrm{cal}$ and mechanical fetal lung maturation. These results are 
relevant since the $0.25 \mathrm{mg} / \mathrm{kg}$ dose of Dex- $\mathrm{PO}_{4}$ and of Beta- $\mathrm{PO}_{4}$ alone result in similar total corticosteroid exposure of the fetus as treatment with Beta- $\mathrm{PO}_{4}+\mathrm{Beta}-\mathrm{Ac}(4)$. However, the short acting steroids cause high fetal blood levels of free Beta or Dex that have no physiological benefit. In fact the lower PIP requirement and trend toward better compliance and VEI, as well the increased expression of surfactant proteins in lambs exposed to Beta- $\mathrm{PO}_{4}+\mathrm{Beta}-\mathrm{Ac}$ suggest an advantage of this treatment over the soluble steroids alone.

\section{STATEMENT OF FINANCIAL SUPPORT}

This work was funded by the Division of Neonatology and Pulmonary Biology, Cincinnati Children's Hospital Medical Center.

Disclosure: The authors have no conflicts of interest.

\section{REFERENCES}

1. Roberts D, Dalziel S. Antenatal corticosteroids for accelerating fetal lung maturation for women at risk of preterm birth. Cochrane Database Syst Rev 2006; 3:CD004454.

2. Brownfoot FC, Gagliardi DI, Bain E, Middleton P, Crowther CA. Different corticosteroids and regimens for accelerating fetal lung maturation for women at risk of preterm birth. Cochrane Database Syst Rev 2013; 8:CD006764.

3. Gilstrap LC, Christensen R, Clewell WH, et al. Effect of corticosteroids for fetal maturation on perinatal outcomes: NIH consensus development panel on the effect of corticosteroids for fetal maturation on perinatal outcomes. JAMA 1995; 273:413-418.

4. Jobe AH, Soll RF. Choice and dose of corticosteroid for antenatal treatments. Am J Obstet Gynecol 2004;190:878-81.

5. Elimian A, Garry D, Figueroa R, et al. 'Betacode Trial' antenatal betamethasone compared to dexamethasone: a randomized controlled trial. Obstet Gynecol 2007;110:26-30.

6. Subtil D, Tiberghien P, Devos P, et al. Immediate and delayed effects of antenatal corticosteroids on fetal heart rate: a randomized trial that compares betamethasone acetate and phosphate, betamethasone phosphate, and dexamethasone. Am J Obstet Gynecol 2003;188:524-31.

7. Crowther CA, Harding JE, Middleton PF, Andersen CC, Ashwood P, Robinson JS; A ${ }^{\star S T E R O I D ~ S t u d y ~ G r o u p . ~ A u s t r a l a s i a n ~ r a n d o m i s e d ~ t r i a l ~ t o ~}$ evaluate the role of maternal intramuscular dexamethasone versus betamethasone prior to preterm birth to increase survival free of childhood neurosensory disability ( $A^{\star}$ STEROID): study protocol. BMC Pregnancy Childbirth 2013;13:104.

8. Althabe F, Belizan JM, McClure EM, et al. A population-based, multifaceted strategy to implement antenatal corticosteroid treatment versus standard care for reduction of neonatal mortality due to preterm birth in low-income and middle-income countries: the ACT cluster-randomised trial. Lancet 2015;385:400-412.

9. Jobe AH, Nitsos I, Pillow JJ, Polglase GR, Kallapur SG, Newnham JP. Betamethasone dose and formulation for induced lung maturation in fetal sheep. Am J Obstet Gynecol 2009;201:611.e1-7.

10. Polglase GR, Hillman NH, Pillow JJ, et al. Positive end-expiratory pressure and tidal volume during initial ventilation of preterm lambs. Pediatr Res 2008;64:517-22.

11. Tan RC, Ikegami M, Jobe AH, Yao LY, Possmayer F, Ballard PL. Developmental and glucocorticoid regulation of surfactant protein mRNAs in preterm lambs. Am J Physiol 1999;277(6 Pt 1):L1142-8.

12. Rayburn WF, Christensen HD, Gonzalez CL. A placebo-controlled comparison between betamethasone and dexamethasone for fetal maturation: differences in neurobehavioral development of mice offspring. Am J Obstet Gynecol 1997;176:842-50; discussion 850-1.

13. Baud O, Foix-L'Helias L, Kaminski M, et al. Antenatal glucocorticoid treatment and cystic periventricular leukomalacia in very premature infants. $\mathrm{N}$ Engl J Med 1999;341:1190-6.

14. Crowther CA, McKinlay CJ, Middleton P, Harding JE. Repeat doses of prenatal corticosteroids for women at risk of preterm birth for improving neonatal health outcomes. Cochrane Database Syst Rev 2015;CD003935.

15. Hagan R, French N, Evans S. et al. Repeated antenatal corticosteroids: growth and early childhood outcomes. Pediatr Res 1997;41:405.

16. Guinn DA, Atkinson MW, Sullivan L, et al. Single vs weekly courses of antenatal corticosteroids for women at risk of preterm delivery: A randomized controlled trial. JAMA 2001;286:1581-7.

17. Jobe AH, Moss TJ, Nitsos I, Ikegami M, Kallapur SG, Newnham JP. Betamethasone for lung maturation: testing dose and formulation in fetal sheep. Am J Obstet Gynecol 2007;197:523.e1-6.

18. Schwab M, Coksaygan T, Samtani MN, Jusko WJ, Nathanielsz PW. Kinetics of betamethasone and fetal cardiovascular adverse effects in pregnant sheep after different doses. Obstet Gynecol 2006;108(3 Pt 1):617-25. 